\title{
CD5L wt Allele
}

National Cancer Institute

\section{Source}

National Cancer Institute. CD5L wt Allele. NCI Thesaurus. Code C119714.

Human CD5L wild-type allele is located within 1q21-q23 and is approximately $67 \mathrm{~kb}$ in

length. This allele, which encodes CD5 antigen-like protein, may play a role in both immunity and apoptosis regulation. 